\title{
Anotações à margem \\ de um belo livro
}

Literotura e Sociedade, São Paulo,

DTLLC.FFLCH-USP, 1998, n, 3, 128 Pp.

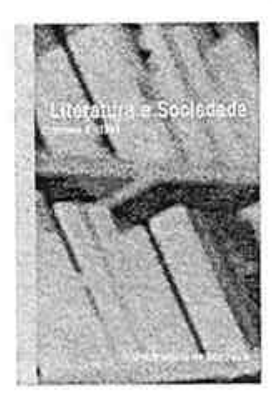

Literatura e Sociedade chega ao terceiro número, dando continuidade ao projeto de publicações do Departamento de Teoria Literária e Literatura Comparada. Neste terceiro número, abdicou-se do tratamento temático, no intuito de criar maior liberdade de colaboração. "Ensaios"se abre com um artigo da professora Maria Elizabeth de Vasconcellos sobre o caráter moralizante das fábulas de Esopo lidas na Idade Média portuguesa; também um caráter moralizante está na presença do livro Sinclair das Ithas, lido por algumas personagens de Machado de Assis, no artigo da professora e pesquisadora Marlyse Meyer, artigo que há algum tempo a revista estava por publicar.

Os ensaios seguintes tratam da literatura brasileira deste século, na forma de diálogo: Raul Antelo fala das relações entre a obra de alguns críticos e/ou criadores modemistas ou não com a psicanálise freudiana ou com Freud; Sandra Nitrini compara as ligações de Ribeiro Couto e Osman Lins com a França, a partir de seus livros de viagem; e Regina Lúcia Pontieri aproxima dois de nossos maiores prosadores modernos, Mário de Andrade e Clarice Lispector, vendo o tratamento dispensado à questão do feminino.

Os dois artigos restantes têm um intuito basicamente teórico: o primeiro, de Walter Moser, professor que visitou o Departamento em 1997, avalia alguns aspectos das relaçóes entre estudos culturais e estudos literários; o segundo, de Leopoldo Waizbort, trata do memorial acadêmico enquanto gênero literário. Ligado ao texto do prof. Waizbort, a seção "Depoimento" publica o memorial de João Luiz Lafetá, professor do Departamento e da Universidade de 1978 a 1996.

"Biblioteca" traz resenhas sobre obras importantes nos estudos literários: a primeira, a edição atualizada da correspondência de Euclides da Cunha; a segunda, o livio em homenagem aos oitentas anos de Décio de Almeida Prado; e a última, o livro mais recente de Davi Arrigucci Jr
Joaquim Alves de Aguiar

Universidade de São Paulo

Gilda de Mello e Souza, O Espirito das Roupas: a Moda no Século Dezenove, São Paulo, Companhia das Letras, 1987.

Há livros pelos quais é quase impossível não se apaixonar à primeira leitura. Penso ser este o caso de O Espirito das Roupas, de Gilda de Mello e Souza, pois trata-se de uma obraprima do moderno ensaísmo brasileiro. Por quê? Em primeiro lugar, p̧elo modo de abordar o assunto: a moda é vista pela autora como fenômeno a um só tempo estético e social. Em segundo lugar, pela prosa perfeita com que o livro foi escrito, uma prosa, como a de Antonio Candido, clássica, discreta, precisa e refinada. Chamam a atençāo, em $O$ Espírito das Roupas, a delicadeza e a argúcia no trato da matéria, a erudição fulgurante e as várias observações de uma ousadia ímpar.A finura do recorte é refletida na finura do estilo, de modo que fundo e forma se equilibram no mesmo nível e com perfeição. Em suma, temos aí uma teoria artística da moda e ao mesmo tempo uma peça inestimável da nossa sociologia da arte e da cultura.

Estamos falando de una obra que muitos gostariam de ter escrito. Mas nem sempre foi assim. Tanto que o livro ficou praticamente esquecido durante quase quarenta anos. Elaborado como tese de doutoramento, sob orientação de Roger Bastide, para o Departamento de Sociologia da USP, O Espírito das Roupas foi publicado, 
com o título de $A$ Moda no Século XIX, na Revista do Museu Paulista, onde permaneceu ganhando poeira, timidamente esperando sua hora e vez, até reaparecer, em 1987, em nova edição, bastante cuidada, pela Companhia das Letras.' Era, até então, podemos dizer, um livro à frente do seu tempo, lançado nos ano 50 para leitores dos anos 80 e 90 . Sua atualidade somente agora pode ser vista com toda a nitidez

Para começar, O Espírito das Roupas antecipou as teses sobre temas tidos como menores, enquadrando-se, assim, no que hoje s habituou a chamar, no melhor sentido que essas expressōes possam ter, de "estudos culturais", "história das mentalidades", "da vida cotidiana" etc. E depois, trata-se de um trabalho que quebrava as barreiras das especializações tão em voga no momento de sua elaboração. Numa época de trabalhos acadêmicos sisudos, O Espíito suavizava o panorama, o que custou a ser percebido. ${ }^{2}$ As artes, a sociologia, a história e a literatura se juntam para formar o ensaio, um ensaio arguto que compartilha suas qualidades com os melhores produzidos no campo dos estudos brasileiros contemporâneos.

Não faz muito tempo, o costureiro Clodovil Hernandes, indagado pelo jornalista e apresentador de tevê Boris Casoy sobre os precos dos vestidos assinados por ele, esquivou-se da pergunta, dizendo, num sorriso irônico, que suas roupas eram "muito caras" e que

Gilda de Mello e Souza, O Espirito das Roupas: a Moda no Século Dezenove, São Paulo, Companhia das Letras 1987. Para facilitar, todas as citaçōes desse livro serão seguidas do número da página, entre parênteses.

2 Sobre a carreira intelectual de Gilda de Mello e Souza, que pertenceu ao grupo da revista Clima, consultar Heloísa Pontes, Destinos Mistos: os Críticos do Grupo Clima em São Paulo: 1940-1968, São Paulo, Companhia das Letras, 1998, sobretudo pp. 187-190. Ver também, da própria autora, a respeito de sua formaçāo, “A Estética Rica ¿a Estética Pobre dos Professores Franceses", Exerććcios de Leitura, Sāo Paulo, Duas Cidades, 1980, pp. 9-54.

3 Estou me referindo zo programa Passando a Limpo, de 10 jan. 1999, transmitido pela Rede Record de São Paulo, sob o comando de Boris Casoy melhor ainda, como as obras de arte autênticas, não podiam ter preço. ${ }^{3}$ A saída só apaentemente banal, nos prende pelo número tes que a enformam: brinca ira, vaidade, arrogância, esperteza, atrevimento, ingenuidade, cabotinismo, uto-estima, ironia, auto-ironia etc., resultando num conjunto com notável teor de comicidade. De fato, conforme o ânimo do elespectador, a resposta pode acordá-lo, fa ali, afirmando o inefável de sua arte "mundo", preso à poltrona diante da televio, em noite de mais um domingão inútil. entre outras coisas de corte e costura assim se posicionando acima de outros grandes nomes de todas as épocas. Até bem pou, antes da crise asiática, volta e meia 位 or algum empresário japonês, num desses entessionista. Mas também é ngraçada a resposta do entrevistado se penarmos que, muito provavelmente, suas rouàs hoje chamadas "emergentes" de al gum quadrilátero da soja ou rede de padaris, que andam em alta, afirmando-se por todos os cantos como novos membros da elite, sob

Nestes tempos neoliberais, parece que 0 pumento público da maioeducada pelos meios de comunicação. Cabe observar que já não temos contracultura dos anos 60 e 70 para fustigar si mesmo, para o entrevistador e para o as fulgurações burguesas, hoje reduzidas ao reinado do ter. Entre as pessoas da minh geração, nessa época, havia os que se sentiam desconfortáveis quando andavam em outro carro que não fosse o Volkswagen, porque este, sendo popular e despretensioso, não agredia tanto a disposição de não ostentar Um músico como Juca Chaves era desprezível porque gostava de exaltar em canções a superioridade do modus vivendi burguês. Num de seus muitos refrões de graça duvidosa, dizia o compositor, aludindo ao padrão aquisitivo dos ricos, com os quais se identificava, e dos pobres, que desqualificava: "eu bebo champagne, você bebe café".

Retomando a questão sobre Clodovil, em que pese o que dissemos sobre a resposta dada por ele a Boris Casoy, há o fato de que ele reivindica para si o estatuto de artista e para a roupa que assina o estatuto de arte. Isso nos reconduz a $O$ Espírito das Roupas, pois a mod é mesmo vista, no livro, como uma dentre as formas da arte. ${ }^{4}$ Vejamos esta definição do trabalho do estilista: "fechado em seu estúdio", como um pintor ou escultor, "o costureiro, ao criar um modelo, resolve problemas de equilíbrio de volumes, de linhas, de cores, de ritmos" (p. 33). Além disso, é a moda "a mais viva, a mais humana das artes", pois o corpo completa aquilo que o artista produziu:"o vestido que escolhemos atentamente na modista ou no 'magasin bon marché' não tem moldura alguma que o contenha e nós completamos com o corpo, o colorido, os gestos, a obra que o artista nos confiou inacabada" (p. 41).
Sendo assim, é possível tratar o objeto da moda com os instrumentos utilizados para a análise da obra de um artista plástico: "deste ponto de vista, os principais aspectos da vestimenta seriam a forma, a cor, o tecido e a mobilidade; da conjugação dos quatro componentes nasceria a obra de arte, embora cad um deles pudesse ser focalizado isoladamente, com seus problemas e soluções" (p. 42).

Nessas e noutras observações sobre o ca ráter artístico da moda, chama atenção o olhar pictórico de Gilda de Mello e Souza, que viria a ser, com todos os méritos, professora de Estética do Departamento de Filosofia da USP. ${ }^{5}$ O olho clínico para os objetos de arte, de uma clareza e precisão impressionantes, marcaria firmemente o seu estilo, imprimindo à sua prosa uma notável plasticidade.Vejamos por exemplo este "exercício de leitura" que funde a descrição da indumentária com a percepçăo das linhas construtivas de uma tela do século XV italiano. A autora referese aos retratos femininos, sujeitos, na época à pompa do toucado:

Admirável exemplo dessa técnica é o "retrato de Senhora" de Pisanello, em que o interesse todo do quadro se concentra não no portentoso rolo estofado e chapeado de ilhoses, que contorna a cabeça, mas no rosto muito nítido e simples para onde nosso olhar é conduzido através de un hábil jogo de linhas: os semicirculos de contas de filigrana do colar combinam-se com o semicírculo em sentido oposto do turbante, a elaboração inferior e a elaboraçāo superior do quadro levando-nos para a zona de interesse - a face pálida de perfil. (p. 38)

Como se vê, aqui a moda fundiu-se à pintura. Não se trata de utilizar a imagem como

4 Gilda de Mello e Souza apreende a moda como "uma arte rítmica por excelência". Ver esta e outras observaçōes instigantes sobre a crítica de arte exercida pela autora, no estudo de Paulo e Otília Arantes, "Moda Caipira", Discurso, Departamento de Filosofia da USP, 1996, n. 26, pp. 33-68.

5 Sobre a atuação de Gilda de Mello e Souza no Departamento de Filosofia da USP, ver Renato Janine Ribeiro, "Apresentação", Discurso, ed. cit., pp. 9-13. 
documento, apenas para demonstrar detalhes da vestimenta feminina da época, mas de observar o traje como parte da estruturação da tela. Não escapa ao ollhar atento o jogo de linhas formando os semicírculos que integram a indumentária ao rosto da figura retratada. A roupa é mostrada no contexto do quadro do mesmo modo que a sua evolução será vista através dos moldes das transformações sociais. Mas também não escaparam aos olhos de Gilda de Mello e Souza as ligaçōes da moda com a arquitetura, sobretudo no que concerne à roupa masculina, pois, no século do dinheiro e das indústrias, foi o homem educado para a vida prática: "os temas invariáveis do industrialismo, abóbadas, túneis, reservatórios de gás, chaminés de fábricas, imprimem-se no subconsciente e o homem se torna cilíndrico, com suas calças, cartola e sobrecasaca" (p. 34).

Mesmo quando analisa um filme ou livro, o olhar pictórico é determinante na apreensão do objeto. Em Oito e Meio, de Federico Fellini, "a imagem não é mais caçada na linha do horizonte pela câmara cinematográfica, mas tem como campo a amplidão da tela. Ousaria dizer que, neste filme, Fellini se aproxima da pintura barroca, ao desprezar a prisão da moldura, anulando-a através da expansão das linhas de força que marcam os eixos dinâmicos da composiçăo". ${ }^{6}$ O enredo de Macunaíma também é visto como se compreendesse um traçado de pintura: "Páginas atrás [...] me referi ao caráter ambíguo da narrativa, atribuindo-o sobretudo ao fato da linha principal do entrecho ver-se com freqüência obscurecida pela ampliação sistemática das linhas laterais". 7

Para Gilda de Mello e Souza, portanto, a moda é uma forma de arte, e como tal dialoga com as outras artes, daí que o seu ensaio revele a cada passo os seus conhecimentos das artes plásticas e da literatura. Mas como a moda é parte das vida dos homens, faz-se necessário o acompanhamento da História e a hordager lhido para estudar. Um dos grandes méritos de O Espírito das Roupas é o poder de desmistificação do seu objeto. A moda pode ser vista como fruto da vontade individual e do capricho, ou como necessidade imposta pela História. Naturalmente, Gilda de Mello e Souza tende à segunda maneira de ver. Para ela, a criatividade dos costureiros se junta às suas intuições sociais, de modo que as flutuações da moda acabam por refletir o andamento da sociedade: "como o poeta", o estilista "é apenas o porta-voz de uma corrente que se esboça e cuja tomada de consciência [ele] antecipa" (p. 31).

Un caso notável dessa combinação de criatividade com intuição social foram as saias "espetaculares de exuberante metragem", assinadas por Christian Dior para as mulheres do pós-guerra. A vestimenta funcionou como desafogo, sobretudo para a classe endinheirada, naqueles anos de "sofrimentos agudos que ainda atormentavam o mundo" (p. 31). Como os golpes de gênio nunca se reduzem à esfera do indivíduo, e como a moda capta com rapidez impressionante os desejos da sociedade, é natural que as conquistas da técrica tenham logo sido incorporadas à elaboraçāo das vestimentas e à extensão da moda às camadas mais amplas da população. Assim, a descoberta das tinturas de anilina fez evoluir os padrões de mixagem das cores dos tecidos; o avanço dos sistemas de iluminação dos ambientes apurou o jogo cromático das roupas; a vulgarização da má quina de costura abriu a idade de ouro dos costureiros; a era do aço permitiu o uso da crinolina; a invenção da prancha colorida tornou a moda mais acessível; as estradas de ferro foram decisivas para divulgar os figurinos ao grande público etc. Em todo o livro a sociedade se projeta na estética, de modo que um plano não pode ser visto sem o outro. $O$ assunto, que tende ao fútil, é, pois, tratado com finura e inteligência, entre outras coisas, porque a autora não perde, em nenhum momento da exposição, seu senso apurado da História.

\section{4}

É sob o signo dos antagonismos de sexo e de classe que se constitui a moda no século XIX $\mathrm{Na}$ era da burguesia e da industrialização, a vestimenta masculina se distingue radicalmente da feminina. A sociedade moderna separa o que produz do que não produz, o utilitário do enfeite, o homem da mulher Assim, enquanto o primeiro se despoja para o exercício da vida prática e competitiva, a segunda, fora da engrenagem econômica, se enche de artimanhas para exercer a sedução, procurando por todos os meios atrair aquele que irá sustentar sua existência na sociedade de classes. É nesse esquema que a moda evolui, porque a roupa é sempre instrumento privilegiado na atração dos sexos: "desde então duas tendências têm-se manifestado nas variações sucessivas da moda: a de devassar o corpo, fazendo $\mathrm{com}$ que o exibicionismo triunfe sobre o pudor, o instinto sexual expandindo-se em formas mais realisticas de expressão, e a de cobri-lo de disfarces, sob a coação do puritanismo e do decoro" (p. 93).

$\mathrm{Se}$ a toilette feminina funcionava como peça decisiva no jogo amoroso do século, variando os seus estilos e chegando a níveis consideráveis de complicação, a roupa masculina passou a ser de uma simplicidade a toda prova. Linhas retas, quase nenhuma variação, cores escuras, tudo próximo à rigidez dos uniformes. Em suma, "o homem se cobrirá de luto" (p. 68), exilado que foi "numa existência sombria, onde a beleza está ausente" (p. 71). O século burguês por exce- lência separa a beleza, feminina, da inteligência, a que se aliava a capacidade de ação, masculina. Por esse motivo, a moda será uma indústria dirigida quase que exclusivamente às mulheres. Mas nem sempre foi assim. $\mathrm{Na}$ época de HenriqueVIII, por exemplo, as roupas, "como as plumagens dos pássaros eram mais suntuosas no sexo masculino que no feminino" (p. 80).

Baudelaire, numa de suas passagens memoráveis, observou e interpretou com melancolia e mordacidade a tristeza da roupa masculina, para ele, o "invólucro do herói moderno":

Não será esta a roupa de que a nossa época precisa; pois ela ainda sofre e carrega em seu magros ombros pretos o símbolo de uma tristeza eterna. O terno e a sobrecasaca pretos não tênn apenas sua beleza política como expressão da situação espiritual pública representada numa imensa procissão de papa-defuntos-papa-defuntos políicos, papadefuntos eróticos, papa-defuntos particulares. Todos temos um enterro a festejar. A roupa do desespero, quase toda igual, prova a igualdade... $\mathrm{E}$ as pregas na fazenda que fazen caretas e que se enroscam como serpentes em volta da carne mortificada, não terāo seu encanto oculto?

Sempre impressiona no poeta de $A s$ Flores do Mal o seu enorme talento para extrai a beleza do feio, o que vai escondido por trás das aparências, o detalhe capaz de revelar o todo. E o que acontece nesse trecho admirável, em que não escapa dos olhos de lince do escritor o poder de revelação da roupa preta dos homens, dispostos na imagem central da "imensa procissão de papa-defuntos". A indumentária passa a ser ela mesma símbolo dos novos tempos, tempos angustiantes, mas a seu modo poéticos. Tempos que mortificam a carne. As derradeiras linhas fazem lem- 
brar o desespero de Laocoonte, as serpentes vistas nas pregas da roupa, mostrando o seu "encanto oculto". A poesia em negativo do objeto tal como foi apreendido revela-se na poesia do texto, engrenada no estilo alegórico de Baudelaire.

$\mathrm{Na}$ verdade, a moda, objeto de consumo, apenas incluiu a burguesia e depois a classe média no rol dos seus usuários, tornando-se um acontecimento fundamentalmente ocidental e burguês. A realeza autêntica permaneceria alheia ao vai-e-vem dos cortes, dos tecidos em uso e das cores. Por esse prisma, a austera corte da Rainha Vitória (e a de D. Pedro II, no Brasil), opunha-se à francesa, comandada por Eugênia, esposa de Napoleão III, plebéia e talvez por isso encarnação do ideal da parvenue. $\mathrm{A}$ imperatriz dos franceses usava a moda para conquistar a admiração de seus súditos, tendo se tornado, assim, "a última soberana européia lançadora de modas e a primeira grande vedete a serviço de uma indústria que se organiza" (p. 133). No rés-do-chão do edificio social, as muIheres pobres certamente não tinham acesso, ou acesso muito restrito, às cintilações da moda.

Nesse ponto, acho que podemos fazer outro desvio de O Espírito das Roupas, lembrando um dos mais pungentes retratos literários que os nossos escritores produziram. Trata-se da apresentação de Capitu em Dom Casmurro, obra-prima de Machado de Assis. Quando ela aparece já estamos no capítulo XIII do romance. Os olhos do narrador se juntam aos do Bentinho adolescente, que fora ele mesmo, o homem que agora nos fala, em

plena maturidade. O leitor se prepara para literatura brasileira, mas é também como se Bentinho, criado na companhia dela, a estivesse vendo pela primeira vez:

Não podia tirar os olhos daquela criatura de catorze anos, alta, forte e cheia, apertada em um vestido de chita, meio desbotado. Os cabelos grossos, feitos em duas tranças, com as pontas atadas uma à outra, à moda do tempo, desciam-lhe pelas costas, Morena, olhos claros e grandes, nariz reto c comprido, tinha a boca fina e o queixo largo. As mãos, a despeito de alguns oficios rudes, eram curadas com anor; não cheiravam a sabões finos nem águas de toucador, mas com água do poço trazia-as sem mácula. Calçava sapatos de duraque, rasos e velhos, a que ela mesma dera alguns pontos.

Observamos no trecho que o narrador descreve a mocinha de cima para baixo, primeiro a cabeça, depois as mãos e os pés, estes calçados nos "sapatos de duraque, rasos e vethos". Provavelmente, o movimento de descida é mais uma estratégia do homem ressentido que não perde a chance de rebaixar a mulher por quem julga ter sido traído. É como se ele a olhasse do alto, das alturas da classe a que pertence e do tempo que passou. Se for assim, o rebaixamento moral acaba sendo reforçado pela descrição da menina pobre, vestida e calçada com modéstia, de hábitos modestos - e singelos também.

A palavra-chave do texto é "apertada": o corpo da moça "alta, forte e cheia" se comprime no "vestido de chita, meio desbotado", de onde parece querer sair, como alguém que anseia por casa maior, mais confortável e mais bem guarnecida. Com efeito, as finanças da famúlia de Capitu não cresciam na proporção do seu corpo, de modo que o

9 Consta que, bern antes de Eugênia, a austriaca Maria Antonieta, esposa de Luís XVI, cultivava excessivamente a moda, para desgosto de sua mãe, a imperatriz Maria Teresa, "que via ocupą̧ōes mais dignas para a rainha", e que chegou a devolver um retrato da filha, pois "aquilo lhe pareceu o retrato de uma atriz e nāo o de uma rainha da França”. Stefan Zweig, Maria Antonieta, Rio de Janeiro, Civilização Brasileira, s.dı, pp. $95-96$. "desbotado" da roupa se une ao "rasos e velhos" dos sapatos, indicando, as duas expressōes, para além da realidade imediata, a passagem do tempo e a estagnação da vida na sua dureza. A vivacidade do retratinho, anti-romântico até a medula, é mesmo surpreendente. Uma vivacidade que se nota no ritmo acelerado das frases, na precisão e economia dos traços. O essencial está todo ali.A modéstia social da adolescente expressa na modéstia do retrato em seco, que não ocupa mais do que um parágrafo do romance.

Dificilmente o leitor se esquecerá da roupa de Capitu, do vestidinho desbotado e dos calçados de pano remendado, peças, como diz a passagem, desgastadas pelo uso prolongado. $O$ retrato da personagem se amplia no retrato de uma moça pobre qualquer, alijada dos esquemas da moda. É interessante observar como o corpo apertado no vestido e na classe a que pertence vai se soltar quando, mais tarde, Capitu se casa com Bentinho. Na lua-de-mel do casal, no afastado Alto da Tijuca, ela se impacienta para retornar à cidade, segundo o narrador, porque queria mostrar a todos sua nova condição de mulher bem-sucedida na sociedade de classes: "A alegria com que pôs o seu chapéu de casada, e o ar de casada com que me deu a māo para entrar e sair do carro, e o braço para andar na rua, tudo me mostrou que a causa da impaciência de Capitu eram os sinais exteriores do novo estado. Não lhe bastava ser casada entre quatro paredes e algumas árvores; precisava do resto do mundo também." (cap. CII)

Naquela altura, já ia longe o tempo da roupinha e dos sapatinhos surrados. Capitu agora pertencia ao universo da moda. Era uma respeitável senhora da burguesia fluminense. A sociedade dava margem à figura do arrivista: "a vestimenta está sempre em evidência e oferece, à primeir todos os observadores, uma indicação do ега, Capitu devia saber disso, pois, como diz o narrador, que suportara mal $\circ$ fastio da mulher no retiro amoroso, que tendia a se prolongar, Capitu queria exibir em público "os sinais exteriores do [seu] novo estado". A atitude do marido se encaixa bem numa observação feita por Gilda de Mello e Souza a respeito da situação da mulher nos esquemas matrimoniais da época: "O casamento era então uma espécie de favor que o homem conferia à mulher, o único meio de adquirir status econômico e social, pois aquela que não se casava era a mulher fracassada, e tinha de se conformar à vida cinzenta de solteirona, acompanhando a mãe às visitas, entregando-se aos bordados infindáveis, à educação dos sobrinhos" (p. 90)

No caso de Dom Casmurro, esse aspecto de ordem social é reforçado pelo psicologismo do herói romântico que é Bentinho, um típico representante do patronato imperial, oposto em tudo à muher, "realista" e procedente de família desfavorecida. De algum modo o narrador, querendo-a romântica como ele, tenta impingir a Capitu o "complexo de Cinderela". Mas o seu intento fracassa, porque Capitu, todas as instâncias da narrativa nos mostram, en termos de inteligência, astúcia e compreensão do mundo ao seu redor, estava muitos passos à frente do marido que a retirara da obscuridade da classe de que provinha. ${ }^{10}$

O eixo da análise, em O Espíito das Roupas, depende, como não poderia deixar de ser, das observações feitas no livro sobre o corte das vestimentas. O corte dita a moda e impõe movimento: do corpo humano e do

$10 \mathrm{Em}$ todo o comentário, sigo de perto a análise feita por Roberto Schwarz em seu ensaio, diga-se de passagem imperdivel, "A Poesia Envenenada de Dom Casmurto", Novos Estudos Cebrap, mar. 1991, n. 29, pp. $85-97$ 
corpo da sociedade. Como dissemos anteriormente, os vetores estético e histórico se cruzam no pensamento de Gilda de Mello Souza. São mesmo admiráveis as ligaçōes tecidas por ela a partir desse entrecruzamento de níveis. Antes do século XIX, a roupa era incômoda e se exprimia, no corte e na ornamentação, como "uma prova visível, oferecida a todos, de que o portador, não se dedicando aos trabalhos manuais, desprezava o desembaraço dos membros e o conforto das vestes" (p. 48).

Essa natureza hierática da vestimenta, o caráter distintivo se sobrepondo ao funcional, se transforma radicalmente quando a aristocracia cede lugar à burguesia vitoriosa, prática e móvel, pragmática até não mais poder. $O$ fato é que as roupas ganharão mobilidade; um mobilidade que de algum modo refletirá as mudanças na escala social, pois as classes estão mais abertas e são "percorridas por movimento contínuo de ascensão e descida" (p. 112). Evidentemente, a mobilidade dos cortes vai espelhar a mobilidade dos estilos, o sobe $e$ desce veloz, como as ações da bolsa, da cotação dos trajes, que ora se encontram ora não sc encontram na moda. Como se vê, a questão da velocidade no século da máquina a vapor está no fundo de todas essas visadas críticas do livro. O tempo acelera e encurta a distância en tre as coisas no espaço; o homem se torn fisicamente mais próximo do seu semelhante; a população e as cidades crescem vertiginosamente na proporção em que aumenta a necessidade de mudanças no comportamento e no hábitos. A moda acompanha todo o processo.

É num contexto assim, de mudanças aceleradas por todos os lados, que surge a figura do arrivista, uma espécie de farsante, compartilhando o mesmo espaço das elites." A imperatriz Eugênia, como já foi lembrado, era o modelo das recém-chegadas, para quem

11 Sobre o florescimento do parvenu na França pós-rapoleônica, ver o ensaio já clássico de Eric Hobsbawm, "A Carreira Aberta ao Talento", A Era da Revoluçös: Europa 1789-1848, trad, Maria Tereza Lopes Teixeira e Marcos Penchel, $6^{2}$ ed., Rio de Janeiro, Paz e Terra, 1977, pp. 203-237. levando as novidades da cidade para o campo;'12 Maria Sílvia de Carvalho Franco estudou a austeridade dos fazendeiros de café no período de acumulação do capital até que os excedentes pudessem ser empregados no conforto e no luxo domésticos. ${ }^{13}$

Gilda de Mello e Souza não avança no tempo, mesmo porque esse não é o seu objetivo em O Espírito das Roupas, mas poderíamos mencionar o rádio, que, dos anos 30 em diante, contribuiria decisivamente para diluir as barreiras entre os espaços urbano e rural, levando a mensagem das cidades aos esquecidos do país. Cheguei a ver, nos meados da década de 1960, na região da antiga Noroeste do Brasil, moças da roça cobertas dos pés à cabeça porque precisavam se proteger dos raios escaldantes, e porque não queriam parecer roceiras queimadas de sol. A cor da pele comprometia em todos os sentidos: escurecer não era bom negócio por motivos raciais e também por causa do preconceito existente contra o trabalho no campo. Clarinhas como leite, à noite colavam os ouvidos no rádio de pilha para ouvir as canções da jovem guarda: queriam por todos os meios saber como era a cara do RonnieVon, forma de atender às curiosidades de moça $\mathrm{e}$ forma, também, de estar sintonizadas com a vida urbana.

A atração pela cidade era mesmo irresistivel; uma atração proporcional ao preconceito que existia contra o caipira, o capiau, o jeca, o homem e a mulher, sobretudo os pobres do campo, a maioria analfabeta, ou semi-analfabeta, em contato direto com a natureza, identificada com o atraso, corporificada nos heróis dos filmes de Mazzaropi, e à mercê do trabalho duro na terra. Com o advento da televisão, seriados como Lassie ensinavam uma nova maneir de ver o campo, tudo limpo e arejado, a dona da casa discreta e bem vestida, sem os calos da enxada nas mãos, com seu avental por cima do vestido claro e pregueado, cintinho na cintura. Era a idealização do country side americano, logo desmentida em certos filmes mais realistas, sem tanto glanour ou tanta mensagem edificante.

Hoje em dia, como estamos cansados de ver, a simbologia do campo é uma das coqueluches da mídia; a mídia que forjou as figuras do "agroboy" e da "agrogirl" e que os elegeu como padrão da boa vida e da elegância também. Tudo conforme o figurino do país grande do norte, pois o caipira "autêntico", o homem pobre e tosco da roça, continua à margem de tudo. Quando ele aparece, encarnando o politizado Sem-Terra, torna-se inimigo da imprensa que se diz liberal: é o invasor perigoso da propriedade alheia e, logo, deve ser tratado como agitador ou bandido. O caipira que interessa é o rico ou o bem-sucedido, o dono de terras vestido de coubbo: calça colada de jeans, botas de bico fino, camisa xadrez, cinto largo e chapéu de vaqueiro.

A moda do rodeio, cópia fiel das competições texanas, tomou conta das cidades do interior paulista e são hoje importantes eventos de mídia, anunciados nos jornais, no rádio e na televisão. Certamente, com todo o seu aparato, rendem lucros consideráveis à indústria cultural, uma indústria que há mais de dez anos vem faturando alto com a chamada "música sertaneja", em geral distante das singelezas da música caipira, melosa, repetitiva, erotizada, mas de um erotismo vulgar, e muito próxima da música country americana. As duplas sertanejas pululam no mercado feito coelhos, todas iguais, cantando do mesmo jeito as mesmas coisas, enjoando os olhos e os ouvidos minimamente exigentes. Uma sessão de Nashville, filmado

12 Ver Gilberto Freyre, Sabrados e Mucambos: Decadência do Patriarcado Rural e Desenvolvimento Urbano, $5^{2}$ ed., Rio de Janeiro, José Olympio/INL, 1977, torno I, pp. 34-35.

3 Ver Maria Sílvia de Carvalho Franco, "O Fazendeiro e seu Mundo", Hornens Livres na Ordem Escravocrata, $3^{2}$ ed. São Paulo, Kairós, 1983, pp. 156-216. 
nos anos 70 por Robert Altman, que empreendeu uma crítica ácida ao ambiente artístico da Meca da música caipira americana não lhes faria mal. No que diz respeito às roupas, é só observar nos shoppings das cidades as lojas com artigos da moda do campo. Nada porém do jeca-tatu. O moço e a moça sertanejos são agora imitações caricaturizadas, não do atraso, mas da riqueza do oeste americano. Estão mais para a reacionária UDR do que para o progressista MST.

A certa altura do século XIX, “a liderança da moda passara aos arrivistas e, principalmente, às 'cocottes' e às atrizes" (p. 133). Tempos depois, podemos acrescentar, seria a vez das divas do cinema. Muitos se lembrarão da classe de Lauren Bacall naqueles filmes em preto e branco dos anos 40; da suavidade de Ingrid Bergman vestida num costume claro, numa cena de rua em Casablanca; dos luxuosos vestidos de Grace Kelly em Janela Indiscreta, do porte de Joan Crawford em Johnny Guitar, da elegância principesca de Audrey Hepburn e assim por diante. No plano masculino, poderíamos destacar o charme de Cary Grant, a graça rebelde de James Dean, a elegância viril de Humphrey Bogart, a timidez ericantadora de Montgomery Clift.

Até os anos 60, se bem me lembro, não se dizia modelo para a moça que desfilava moda Elas eram chamadas de manequins. Twiggy chegou a ser uma celebridade por ter ajudado a divulgação da minissaia, criação de Mary Quant e talvez o maior acontecimento da história da moda nesta segunda metade do século.Veruschka foi outra manequim famosa. Ao contrário da minúscula Twiggy, era moça espichada, cujos traços, eslavos provavelmente, tendiam ao exótico. Foi grande o fascínio que Veruschka exerceu naquele tempo. Era uma espécie de protótipo da mulher do futuro e virou figura cult: seu corpo chegou a ser inteiramente pintado pelo escritor cubano, radicado em Paris, Severo Sarduy.

No Brasil, Duda Cavalcante abriu uma série que culminaria com as modelos de hoje Linda Evangelista por exemplo, de carreira internacional, famosa e muito bem paga.Vivemos a fase de ouro dos grandes desfiles de moda. Eles enchem as páginas dos diários e das revistas, tomam fatias dos telejornais e não raro são transmitidos pela televisão.Longe se vão os tempos em que víamos no cinema o homem conduzindo a mulher a uma casa de roupas caras, a gerente providenciando um desfile privé nalguma parte da loja, com manequins desfilando roupas para a heroína que escolhia ali, na pele da outra, o que comprar. Os desfiles tornaram-se espetáculos para multidões, e as modelos, não todas evidentemente, estrelas da mídia.

Nas décadas de 1950 e 1960, quando elas sequer tinham nascido, vivíamos a época das misses. Os concursos de beleza, que eram em parte desfiles de moda, davam oportunidade às moças - em geral, como as modelos, oriundas da classe média - de ficarem famosas e, muitas vezes, dar um salto na vida, casandose com algum ricaço de olho nas passarelas. As misses, podemos dizer, são as avós das atuais modelos. Mas ao contrário das moças de hoje, não estavam ali, nos concursos, para faze carreira, até porque eram tomadas por rainhas, com direito a faixa, manto, cetro e coroa. Cumpriam seu "reinado" de um ano sem poder casar; depois retomavam a vida de ostracismo ou de fama. Quanto mais sucesso fizesse a miss, maiores as chances de um matrimônio milionário.

Viviam um sonho de Cinderela, muitas vezes transformado em realidade. Martha Rocha, por exemplo, tornou-se figura nacional e foi durante décadas a "namorada do Brasil".' 'lodo brasileiro médio teria gostado de admirar de perto aquele "violão baiano" naquela pele de seda clara, aqueles cabelos anelados, aqueles olhos espetaculares, aqueles dentes perfeitos mostrados no belo e largo sorriso. Nāo chegou a ser Miss Universo, segundo reza a lenda, por ter duas polegadas a mais que a medida-padrão (sic). Mas isso deu-lhe um charme todo especial: era a beleza máxima do país injustiçada pelo júri do concurso internacional realizado nos Estados Unidos. Anos depois de Martha, uma gaúcha e outra baiana trariam o título que ela não conseguira trazer aos brasileiros. Foram recebidas como se recebem os heróis nacionais, em carro aberto, aplaudidas nas ruas pela massa.

Como o cinema nacional sempre foi incipiente e praticamente nulo na fabricação de ídolos; e como a televisão nāo tinha ainda se firmado nesta espécie de variante tropical de Hollywood em que se transformou, sobretudo a Rede Globo em seu setor de telenovelas, as misses talvez suprissem a nossa falta de estrelato cinematográfico. Isso deve explicar, em parte ao menos, o clamor popular naquelas noites de coroação em que se enchiam salōes de clubes e ginásios de esportes para aplaudir ou vaiar aquelas moças competindo na passarela diante de jurados e público, como certos animais são levados a competir nas feiras agropecuárias.

A fórmula desses concursos entrou em declínio por volta dos anos 70, quando ganharam fôlego as manifestações feministas. Tornou-se "cafona" ser miss. A época coincide com a ascensão das modelos, que, ao menos em princípio, não são apenas mulheres bonitas se exibindo por trás das roupas caras dos estilistas de renome. Sendo profissionais que fazem carreira, firmaram-se enquanto "individuos" e puderam florescer em paz. ${ }^{14} \mathrm{E}$ depois, o feminismo também não tardaria a declinar como bandeira de luta. Nos dias que correm, vemos as mães da classe média, tal como as progenitoras das mis-

ses, fazerem o diabo para introduzir suas fiIhas nos meios da moda. O sonho do casamento bem-sucedido foi adiado pela procura do dinheiro fácil, vindo com a fama obtida da noite para o dia, pelo simples fato de que a filha é bonita, fotogênica e tem porte. Há quem prepare o "book" da menina, para divulgar e vender suas imagens, antes mesmo que ela chegue à adolescência. Forma sutil de prostituição, um pouco na Iinha de Pretty Baby do diretor Louis Malle?

8

Decerto aquele antagonismo de sexo e de classe, tão visível na roupa do século XIX e por isso mesmo ponto central no livro de Gilda de Mello e Souza, foi atenuado, no plano da moda, a partir da época de ouro dos "hippies". ${ }^{15}$ O homem, principalmente, sacrificado pelo terno e pela gravata e por muito tempo "acomodado à monótona existência do linho e da lã" (p. 71), suavizou sua aparência, tornando-a menos viril, graças à onda de androginia que tomou conta do mundo dos jovens. O terno deixou de ser obrigatório, e as cores, antes privilégio feminino, invadiram a indumentária masculina. Do James Stewart de Vertigo ao Peter Fonda de Easy Rider parece ter transcorrido um século e não apenas uma década. As nulheres, por seu lado, despiram-se mais. O corpo e, conseqüentemente, a moda, aproximou-se do natural.

Foi assim a juventude contestou a tirania da roupa burguesa, formal, cara e identificada com o poder na sociedade de classes. Saído das zonas rurais do oeste americano, o bluc

14 A carreita atraente das modelos vem, nos últimos anos, se estendendo aos rapazes, que pisam meio sem grą̧a na passarela, un território ainda quase que exclusivamente feminino.

15 Vale lembrar que, antes dos hippies contribuírem para a diluição do contraste na aparência dos sexos, a Revolução Clinesa já tinha operado o mesno fenômeno, evidentemente comı propósitos políticos, fazendo as mulheres se vestirem como homens naquela espécie de uniforme que consagrou a imagem de un povo voltado para trabalho e para a construção de uma nova civilização, em cuja base estaria uma sociedade jgualitária. 
jeans, na forma da "calça Lee", não por acaso antes chamada por aqui de "calça rancheira", invadiu o mercado de roupas e, pode-se dizer foi ele, tecido resistente e despojado, o responsável pelo advento da "moda de massa".

$O$ artesanato também entrou na ordem do dia, podendo ser visto nas camisetas pintadas, nas batas ao estilo indiano, no couro cru das boisas, enfeites e sandálias. A liberdade era uma palavra de ordem e nunca, antes ou depois, os jovens se afirmaram tanto enquanto grupo social. Uma canção da época dizia: "não confio em ninguém com mais de trinta anos"; falava-se muito em "poder jovem"; o status burguês era alvo de crítica cerrada; Gal Costa recitava numa música de Roberto e Erasmo Carlos: "é o amor [e não o dinheiro e a posição social] que faz o homem". Eram tempos de contracultura e tal vez o maior acontecimento teatral do período (1965-1970, mais ou menos) tenha sido Hair que percorreu o mundo, ficando anos em cartaz, levando sua mensagem musical à juventude e reforçando os protestos contra o comportamento burguês, dominante.

A roupa, portanto, acompanhou a "revolução", e os padrões de elegância se alteraram.Janis Joplin, por exemplo, estava elegante, naturalmente ao modo underground, quando se apresentou, lançando-se ao grande público e a uma carreira tão fulgurante quanto meteórica, no festival pop de Monterey, em 1967. Diga-se de passagem que eram tem- pos de grandes festivais de rock ao ar livre, $O$ de Monterey, o de Woodstock, o de Altamont, o da Ilha de White. Esses eventos reuniam multidōes de jovens, para ouvir música, dançar, amar e viajar no efeito das drogas.Viviase o apogeu da música pop e, em termos de comportamento, a avassaladora americanização do mundo.

Como não poderia deixar de ser, findo o ciclo curto das contestaçōes, a indústria da moda incumbiu-se de capitalizar, em escala mundial, as conquistas da época: informalidade, liberdade no vestir, colorido nas roupas etc. Nos desfiles dos grandes estilistas do momento, pode-se ver a mistura do forma com o informal, do clássico com o espalhafatoso, do jeans com a seda etc. $\mathrm{Na}$ verdade, os anos 60 fundiram elementos e estilos variados, puxando a maneira de vestir para a roupa juvenil: descontraídos, o jovem e o velho podem, nos dias de hoje, usar o mesmo tipo de traje e calçar o mesmo tênis. Como não poderia deixar de ser, também depois que John Lennon decretou o fim do sonho, a grande maioria dos rebeldes de outrora não tardou a integrar-se nos esquemas de competição profissional da sociedade capitalista, que parece mesmo renascer das cinzas a cada crise. Mas isso é assunto vasto demais para os limites destas anotações à margem de um belo livro.

Americana, 31 de janeiro de 1999

\section{Apêndice}

